\title{
Recent Spectrum of Acute Viral Hepatitis in Children: An Experience in a Tertiary Centre of Bangladesh
}

\author{
Salahuddin Mahmud ${ }^{1 *}$, Syed Shafi Ahmed ${ }^{2}$, Manzoor Hussain ${ }^{3}$, Mahenaz Afroz ${ }^{4}$, Farhana Tasneem ${ }^{5}$ \\ ${ }^{1}$ Assistant Professor, Pediatric Gastroenterology, Hepatology \& Nutrition, Bangladesh Institute of Child Health, Dhaka Shishu (Children) Hospital, \\ Bangladesh
}

${ }^{2}$ Professor \& Head, Pediatric Gastroenterology, Hepatology \& Nutrition, Bangladesh Institute of Child Health, Dhaka Shishu (Children) Hospital, Bangladesh

${ }^{3}$ Professor \& Head, Pediatric Medicine \& Pediatric Cardiology, Bangladesh Institute of Child Health, Dhaka Shishu (Children) Hospital, Bangladesh ${ }^{4}$ Assistant Professor of Gynaecology \& Obstetrics, National Institute for Cancer Research Hospital (NICRH), Bangladesh

${ }^{5}$ Registrar, Neonatology, Apollo Hospitals, Bangladesh

Submission: March 22, 2017; Published: July 01, 2017

"Corresponding author: Salahuddin Mahmud, Assistant Professor, Dhaka Shishu (Children) Hospital, Dhaka, Bangladesh, Email: drsmbablu@gmail.com

\section{Abstract}

Background: Acute viral hepatitis is a major public health problem in the world affecting millions of children every year despite the availability of vaccines, prophylactic measures and improved sanitation.

Objective: To determine the etiologies, clinical features and biochemical parameters of acute viral hepatitis among hospitalized children in Bangladesh.

Materials \& Methods: A prospective, descriptive study was done in the department of Pediatric Gastroenterology, Hepatology \& Nutrition, Dhaka Shishu (Children) Hospital, Dhaka, Bangladesh from January 2016 to December 2016 among 100 consecutive hospitalized children who presented with acute hepatitis of viral etiology in between 1-15 years of age were included in the study.

Results: Out of 100 icteric children, most of the children were positive for anti-HAV IgM 76 (76.0\%), followed by anti-HEV IgM 14 (14.0\%). Four (4.0\%) cases were found with positive for HBsAg \& anti-HBcIgM, anti-HCV 2 (2.0\%) and anti-HAV with anti-HEV co-infection 4 (4.0\%). In 1-5 year age group, only anti-HAV IgM 9 (11.8\%) was found. In 5-10 year age group, again anti-HAV IgM 42 (55.2\%) was the dominant one followed by anti-HEV IgM 5 (35.7\%). Anti-HEV IgM (64.3\%) was the supreme one in 10-15 year age group followed by anti-HAV IgM 25 (33\%). Total 4 (4.0\%) children having (anti-HAV IgM with anti-HEV IgM) co-infection. Two of them in 5-10 year age group and another 2 in $>10$ year age group. Four (4.0\%) children having acute HBV infection evident by HBsAg \& anti-HBclgM positive. Again 2 of them in 5-10 year age group and another 2 in $>10$ year age group. Only $2(2.0 \%)$ child having HCV evident by anti-HBC positive. One in 5-10 year age group and another 1 in $>10$ year age group. Most of the children presented with jaundice $100(100 \%)$, anorexia 100(100\%), nausea \& vomiting 88 (88\%), low grade fever 65 (65\%), with right upper abdominal pain 73(73\%). Pale stool 18(18\%) \& pruritus 16(16\%) may present due to cholestasis except HCV. On examination, hepatomegaly (94\%) may present almost all cases of viral hepatitis and in $24.0 \%$ cases splenomegaly present. In $14 \%$ cases, sign's of ascites present with the evidence of fluid thrill and/or shifting dullness. No significant difference observed regarding clinical presentation. Maximum number 100(100\%) of patients had increase serum bilirubin, ALT \& AST. Alkaline phosphatase $20(20.0 \%)$ may increase in a case of pale stool (cholestasis). ALF 14(14.0\%) may develop with low serum albumin 14(14.0\%) and increase prothrombine time/INR 14(14.0\%). No significant difference observed regarding biochemical parameter. In ultrasound findings, hepatomegaly (93.0\%) was found in most of the cases followed by splenomegaly (23.0\%), gall bladder wall thickening (33.0\%), gall bladder sludge (23.0\%), hepatosplenomegaly (23.0\%) and ascites (16.0\%). Normal ultrasound was found in 3.0\% cases. Out of 100 admitted patients, 67(67.0\%) were having herbal medicines at the time of admission.

Conclusion: Acute viral hepatitis due to HAV is the commonest followed by HEV. HAV is supreme in 1-10 year age group \& HEV is superior in $>10$ year age group. There was no significant difference between clinical and biochemical parameter of different viruses. Although increasing awareness, education \& knowledge, most of the children having herbal medicines at the time of admission.

Keywords: Acute viral hepatitis; Hepatitis A; Hepatitis B; Hepatitis C; Hepatitis E; Co-infection; anti-HAV IgM; anti-HEV IgM; HBsAg; antiHBcIgM; Anti-HCV 


\section{Introduction}

Hepatitis means "inflammation of the liver". Five types of viruses can cause viral hepatitis. Of these, the most common cause of infection is one of four viruses: hepatitis A, B, C or E. Hepatitis D, also referred to as hepatitis D virus or hepatitis delta virus (HDV) is considered to be a subviral satellite because it can propagate only in the presence of the hepatitis B virus (HBV) [1]. Acute viral hepatitis in children is a major public health problem in both developing and developed countries [2-8]. Despite the availability of vaccines, prophylactic measures and improved sanitation, it affecting millions of children every year [5]. The clinical spectrum of AVH ranges from entirely subclinical and inapparent infection to rapidly progressing and fulminant hepatic failure. Hepatitis A (HAV) and E (HEV) viruses are fecoorally transmitted and self-limiting; whereas hepatitis B (HBV), C (HCV) and D (HDV) are transmitted parenterally and may progress to chronic hepatitis [9].

Hepatitis A virus (HAV) is a single stranded non-enveloped virus belonging to the Picornaviridae family. It is classically spread via the faecal-oral route and is closely related to the bad hygienic and sanitary conditions in the community [10]. It is the most common cause of acute viral hepatitis worldwide. Globally it is responsible for at least 1.4 million new infections each year. Although infection with $\mathrm{HAV}$ is often mild and asymptomatic in young children, the disease can be severe in adults. The distribution and prevalence of HAV infection is very closely related to local hygiene and sanitation conditions [5]. In the World Health Organization (WHO) South-East Asia Region, the annual number of acute cases of hepatitis $A$ is estimated to be 400000 , with 800 deaths. In the 1980s; the presence of the anti-hepatitis A virus antibody (anti-HAV) was detected in more than $90 \%$ of children aged 15 years, and almost everyone above 25 years of age in the WHO South-East Asia Region; indicating that they had been infected with hepatitis Avirus [1]. The highest incidence of hepatitis A infection has previously been reported in developing countries of Africa, Central and South America and South-East Asia. Bangladesh is considered to be a country where hepatitis A infection is hyper-endemic with $100 \%$ of children $\leq 6$ years of age exposed and immune to HAV [5]. Since 1992, safe and effective vaccines against HAV have been made available worldwide. Indian Academy of Pediatrics recommends two doses for any of the licensed vaccines which has to be given six months apart to children aged one year or older. In immune compromised individuals and for post-exposure prophylaxis (PEP), inactivated vaccines are preferred [10].

Hepatitis E virus is a positive stranded; non-enveloped RNA virus which is the only virus within the genus Hepevirus and the family Hepeviridae. It is primarily spread via faecal-oral route but other modes like vertical (mother to child) and parenteral (blood transfusion) transmission have been documented though the clinical implications remain debatable $[10,11]$. It is an emerging pathogen, causes significant disease in endemic countries and is the leading cause of enterically transmitted viral hepatitis illness globally. Large annual epidemics are attributed to HEV and studies suggest that HEV is etiologically responsible for $10 \%-95 \%$ of admitted cases of hepatitis across South Asia [5]. In Member States of the WHO South-East Asia Region; annual symptomatic cases of hepatitis $\mathrm{E}$ are estimated at 12 million, with 42000 deaths and 1800 stillbirths [1]. More than 50\% of global deaths from hepatitis E occur in the Region Globally, prevalence rates of antibody to hepatitis E virus (anti-HEV) vary by region; population and circulating genotypes of HEV, with unexpectedly high seropositivity in some developed settings [5]. Provision of safe; clean drinking water, proper sewage disposal and maintaining good personal hygiene (e.g. hand washing) are imperative to control HEV outbreaks $[10,11]$.

Hepatitis B virus (HBV) is a double stranded DNA virus belonging to the family Hepadnaviridae. HBV is transmitted via permucosal or percutaneous exposure to infected body fluids or blood products and has an incubation period averaging around four months. Transmission is known to occur vertically from an infected mother to child, horizontally (e.g. between children in a household), sexually and parenterally (e.g. via blood transfusions; intravenous drug abuse; etc.) [10]. The prevalence of HBV infection varies from country to country and within countries; having a close association with behavioral, environmental host factors. It has been estimated that there are approximately 350 million HBV carriers in the world, of whom $80 \%$ are Asians. There are approximately 100 million hepatitis B carriers in the South-East Asia Region, and they account for more than $5.6 \%$ of the global population [1]. Over $90 \%$ of infants, $50 \%$ of children and $5 \%$ of adults with acute hepatitis B will develop chronic or long-term infection [5]. Globally in 2013, approximately $686,000 \mathrm{HBV}$ infected persons died from causes related to acute infection $(69,000$ deaths); cirrhosis $(3,17,000$ deaths $)$ and hepatitis B associated liver cancer (300,000 deaths) [12]. More than 300,000 people are estimated to die each year in the South-East Asia Region as a result of the chronic consequences of hepatitis B, particularly cirrhosis and liver cancer [11]. Current prevalence of hepatitis B (based on seropositivity of HBsAg) in Bangladesh 2.35\% [13]. However, among high-risk populations, the sero-prevalence of HBsAg is as high as $29 \%$. Other study shows about $7 \%-10 \%$ population have hepatitis B infection, and $3 \%-5 \%$ pregnant mothers are carrying the hepatitis $B$ virus in Bangladesh. Carrier rate is very high, ranging from $9 \%-12 \%$ in Bangladesh, Korea, Myanmar, Thailand [5]. Prevention of HBV infection should include vigilant screening of blood and blood products and routine testing of tissue and organ donors. Motherto-child transmission can be prevented by routine screening of mothers and providing post-exposure prophylaxis (PEP) to all infants born to infected mothers. A PEP regimen consisting of hepatitis B immunoglobulin (HBIg) and vaccination can prevent infection of an infant in more than 90 per cent of cases [10].

The HCV is an enveloped; single stranded RNA virus belonging to the family Flaviviridae. HCV is spread via percutaneous or 
permucosal exposure to infectious blood or blood products. The high risk groups identified for HCV infection are those receiving multiple blood transfusion (e.g. thalassaemics), engaging in unsafe sexual practices health care workers and transplant recipients. Globally, HCV is the predominant cause for posttransfusion hepatitis [10]. The WHO South-East Asia Region has about 30 million hepatitis C carriers, which is more than $1.6 \%$ of the total population [1]. The number of deaths per year due to HCV-related diseases continues to increase [10]. According to estimates from the Global Burden of Disease study; the number of deaths due to hepatitis $C$ was $3,33,000$ in $1990,4,99,000$ in 2010 and 7,04,000 in 2013. A more recent systematic review estimated that 115 million persons are anti-HCV (antibody to HCV) positive and 80 million have chronic infection. The increase in number of deaths reflects the high incidence of hepatitis C [14]. There is lack of representative population study in Bangladesh regarding prevalence of HCV infection [15]. In the past, it was $2.4 \%$ [16]. In a recent study from Mahtab et al. that was $0.88 \%$. Preventing HCV should follow a multipronged approach which includes educational counselling regarding the modes of spread of HCV directed not only to the high risk groups but to the general population as well [10]. This study was carried out to know the epidemiology of infective hepatitis by means of various viral markers among hospitalized children along with their clinical presentation and biochemical investigations.

\section{Materials \& Methods}

A prospective, descriptive study was conducted in the department of Pediatric Gastroenterology, Hepatology \& Nutrition, Dhaka Shishu (Children) Hospital, Dhaka, Bangladesh from January 2016 to December 2016. After informed written consent from parents/guardians, a total number of 100 consecutive children of acute hepatitis in between 1-15 years of age were included in the study. Acute hepatitis were diagnosed on the basis of clinical (Jaundice $<3$ months of age; right upper abdominal pain, anorexia, nausea, vomiting, low grade fever, pale stool, pruritus, tender hepatomegaly with or without ascites and without any stigmata of chronic liver disease); biochemical [(elevation of serum bilirubin, alanine aminotransferase (ALT), aspartate transaminase (AST), alkaline phosphatase (ALP) normal or low, serum albumin with or without raised prothrombin time/International Normalization Ratio (PT/INR)] and ultrasonography of hepatobiliary system [hepatomegaly (most sensitive sign), with or without splenomegaly, ascites, gall bladder wall thickening with or without sludge and overall echotexture is often decreased]. Acute liver failure (ALF) was diagnosed by PT $>15$ sec or INR $>1.5$ with features of encephalopathy OR PT $>20$ sec or INR $>2.0$ with or without features of encephalopathy. Patients were also tested for Anti-HAV IgM, anti-HEV IgM, HBsAg, Anti-HBcIgM and Anti-HCV. Disease which have clinical presentation of acute hepatitis without hepatotropic viral (HAV, HBV, HCV, HEV) etiology like TORCH infection, enteric fever, malaria, dengue, hemolytic anemia, Wilson's disease, autoimmune and drug induced jaundice were excluded from the study. History, clinical findings and laboratory results were recorded in a pretested semi-structured questionnaire. Data were analyzed by Statistical Package of Social Science (SPSS) version 11.5 programme.

\section{Results}

Out of 100 acute hepatitis children, 9 (9.0\%) in 1-5 yrar age group, $52(52.0 \%)$ in 5-10 rear age group and 39 (39.0\%) in 1015 year age group (Table 1 ).

Table 1: Age distribution of studied children.

\begin{tabular}{|c|c|c|}
\hline Age (Years) & Frequency $\mathbf{( n = 1 0 0 )}$ & Percentage (\%) \\
\hline $1-5$ & 9 & 9.0 \\
\hline $5-10$ & 52 & 52.0 \\
\hline $10-15$ & 39 & 39.0 \\
\hline
\end{tabular}

Among studied children, 62(62.0\%) were male and 38 (38\%) were female. So, male: female ratio was 1.6:1 (Figure 1).

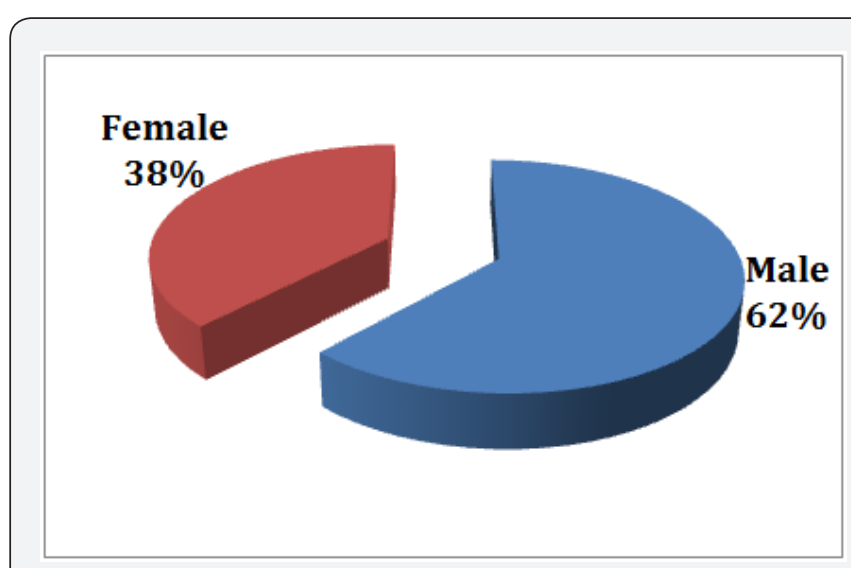

Figure 1: Sex distribution of studied children.

Out of 100 icteric children; most of the children were positive for anti-HAV IgM 76 (76.0\%); followed by anti-HEV IgM 14(14.0\%). Four (4.0\%) cases were found with positive for HBsAg \& anti-HBcIgM, anti-HCV 2(2.0\%) and anti-HAV with antiHEV co-infection 4(4.0\%) (Figure 2).

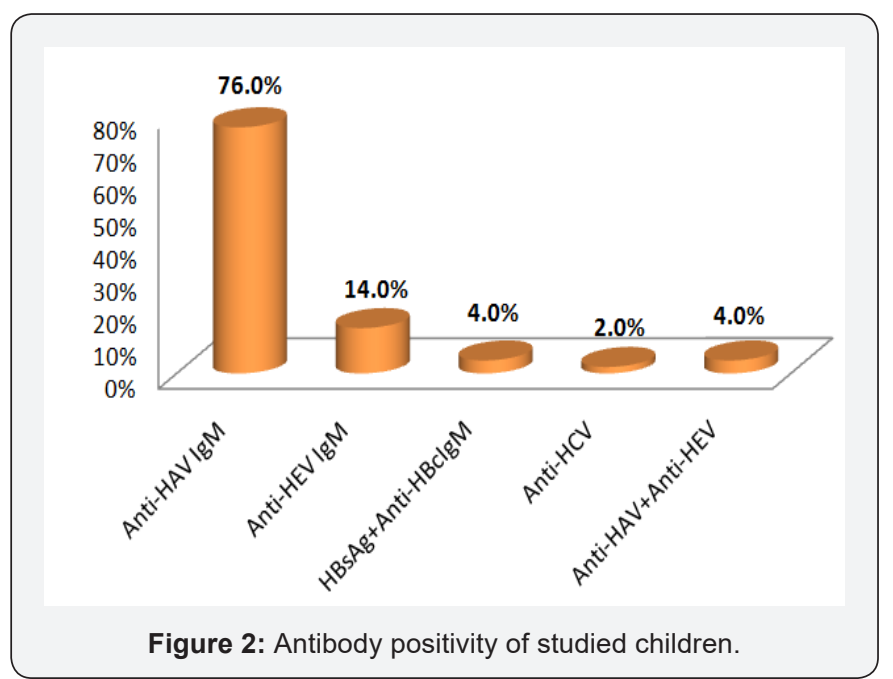


In 1-5 year age group, only anti-HAV IgM 9 (11.8\%) was found. In 5-10 year age group, again anti-HAV IgM 42(55.2\%) was the dominant one followed by anti-HEV IgM 5(35.7\%), antiHAV IgM plus anti-HEV IgM 2(50.0\%), HBsAg plus anti-HBcIgM 2 $(50.0 \%)$ and anti-HCV $1(50 \%)$. In $>10$ year age group, anti-HEV IgM $9(64.3 \%)$ was the dominant one followed by anti-HAV IgM 25(33.0\%), anti-HAV IgM plus anti-HEV IgM 2(50\%), HBsAg plus anti-HBcIgM 2(50.0\%) and anti-HCV 1(50.0\%) (Figure 3).

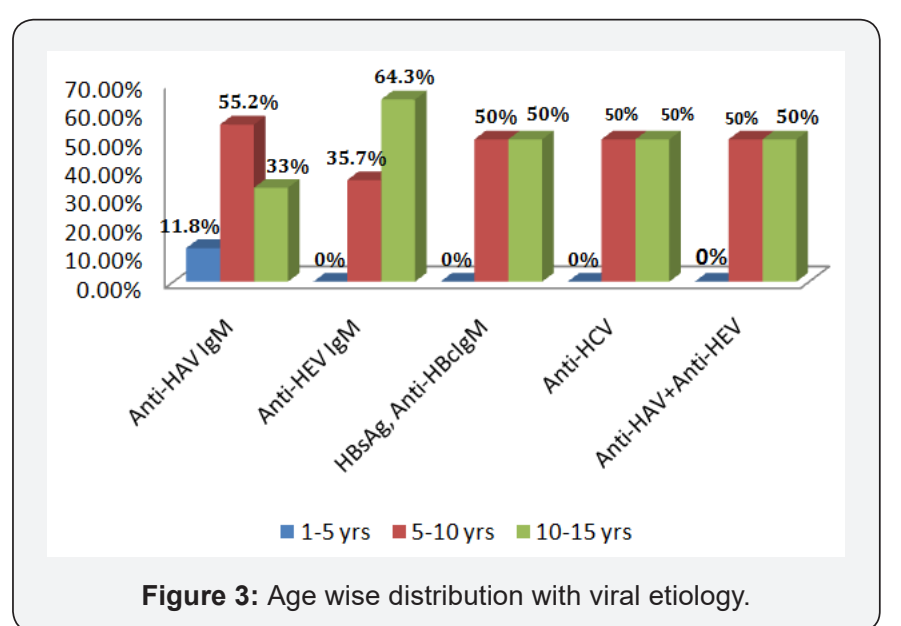

Most of the children presented with jaundice $100(100 \%)$; anorexia $100(100 \%)$, nausea \& vomiting $88(88.0 \%)$, low grade fever $65(65.0 \%)$ with right upper abdominal pain $73(73 \%)$. Pale stool 18(18.0\%) \& pruritus16 (16.0\%) may present due to cholestasis except HCV. On examination; hepatomegaly (94.0\%) may present almost all cases of viralhepatitis and $24.0 \%$ cases splenomegaly present. In $14.0 \%$ cases sign's of ascites present with the evidence of fluid thrill and/or shifting dullness. No significant difference observed regarding clinical presentation (Table 2). Maximum number $100(100 \%)$ of patients had increase serum bilirubin, ALT \& AST. Alkaline phosphatase $20(20.0 \%)$ may increase in a case of pale stool (cholestasis). ALF $14(14.0 \%)$ may develop with low serum albumin $14(14.0 \%)$ and increase prothrombine time/INR $14(14 \%)$. No significant difference observed regarding biochemical parameter (Table 3). In ultrasound findings, hepatomegaly (93.0\%) was found in most of the cases followed by splenomegaly $(23.0 \%)$, gall bladder wall thickening $(33.0 \%)$, gall bladder sludge $(23.0 \%)$, hepatosplenomegaly $(23.0 \%)$ and ascites $(16.0 \%)$. Normal ultrasound was found in $3.0 \%$ cases (Figure 4 ). Out of 100 admitted patients, $67(67 \%)$ were having herbal medicines at the time of admission (Figure 5).

Table 2: Clinical presentation of children in virus specific hepatitis.

\begin{tabular}{|c|c|c|c|c|c|}
\hline Clinical Presentation & HAV $n=76(\%)$ & HEV $n=14(\%)$ & HBV $n=4(\%)$ & HCV n=2(\%) & HAV+HEV $n=4(\%)$ \\
\hline Jaundice & $76(100.0)$ & $14(100.0)$ & $4(100.0)$ & $2(100.0)$ & $4(100.0)$ \\
\hline Abdominal pain & $55(72.3)$ & $11(78.0)$ & $3(75.0)$ & $1(50.0)$ & $3(75.0)$ \\
\hline Anorexia & $76(100.0)$ & $14(100.0)$ & $4(100.0)$ & $2(100.0)$ & $4(100.0)$ \\
\hline Nausea \& vomiting & $68(89.4)$ & $13(92.8)$ & $3(75.0)$ & $1(50.0)$ & $3(75.0)$ \\
\hline Pale stool & $14(18.4)$ & $3(21.4)$ & $1(25.0)$ & $0(0.0)$ & $1(25.0)$ \\
\hline Pruritus & $12(15.7)$ & $2(14.2)$ & $1(25.0)$ & $0(0.0)$ & $1(25.0)$ \\
\hline Fever & $48(63.1)$ & $10(71.4)$ & $3(75.0)$ & $1(50.0)$ & $3(75.0)$ \\
\hline Hepatomegaly & $72(94.7)$ & $13(92.8)$ & $3(75.0)$ & $2(100.0)$ & $4(100.0)$ \\
\hline Splenomegaly & $19(25 \%)$ & $3(21.4)$ & $1(25.0)$ & $0(0.0)$ & $1(25.0)$ \\
\hline Ascites & $8(10.5)$ & $2(14.2)$ & $2(50.0)$ & $0(0.0)$ & $2(50.0)$ \\
\hline
\end{tabular}

Table 3: Biochemical parameters of children at first presentation.

\begin{tabular}{|c|c|c|c|c|c|}
\hline Biochemical Parameters & HAV n=76(\%) & HEV n=14(\%) & HBV $n=4(\%)$ & HCV $n=2(\%)$ & HAV+HEV $n=4(\%)$ \\
\hline \multicolumn{6}{|c|}{ Total serum bilirubin(mg/dl) } \\
\hline $\begin{array}{c}<5 \\
5-10 \\
>10\end{array}$ & $\begin{array}{c}42(55.2) \\
29(38.2) \\
5(6.6)\end{array}$ & $\begin{array}{l}2(14.3) \\
5(35.7) \\
7(50.0)\end{array}$ & $\begin{array}{c}0(0.0) \\
2(50.0) \\
2(50.0)\end{array}$ & $\begin{array}{c}0(0.0) \\
1(50.0) \\
1(50.0)\end{array}$ & $\begin{array}{c}0(0.0) \\
1(25.0) \\
3(75.0)\end{array}$ \\
\hline \multicolumn{6}{|c|}{$\operatorname{ALT}(U / L)$} \\
\hline $\begin{array}{c}<500 \\
500-1000 \\
>1000\end{array}$ & $\begin{array}{l}38(50.0) \\
25(32.8) \\
13(17.2)\end{array}$ & $\begin{array}{c}2(14.3) \\
2(14.3) \\
10(71.4)\end{array}$ & $\begin{array}{c}0(0.0) \\
2(50.0) \\
2(50.0)\end{array}$ & $\begin{array}{c}0(0.0) \\
1(50.0) \\
1(50.0) \\
\end{array}$ & $\begin{array}{c}0(0.0) \\
1(25.0) \\
3(75.0) \\
\end{array}$ \\
\hline \multicolumn{6}{|c|}{$\operatorname{AST}(U / L)$} \\
\hline $\begin{array}{c}<500 \\
500-1000 \\
>1000\end{array}$ & $\begin{array}{l}36(47.3) \\
26(34.2) \\
14(18.4)\end{array}$ & $\begin{array}{c}2(14.3) \\
2(14.3) \\
10(71.4)\end{array}$ & $\begin{array}{c}0(0.0) \\
2(50.0) \\
2(50.0)\end{array}$ & $\begin{array}{c}0(0.0) \\
1(50.0) \\
1(50.0)\end{array}$ & $\begin{array}{c}0(0.0) \\
1(25.0) \\
3(75.0)\end{array}$ \\
\hline
\end{tabular}




\section{Advanced Research in Gastroenterology \& Hepatology}

\begin{tabular}{|c|c|c|c|c|c|}
\hline \multicolumn{6}{|c|}{ Alkaline phosphatase(U/L) } \\
\hline $\begin{array}{c}<300 \\
300-600 \\
>600\end{array}$ & $\begin{array}{l}30(39.4) \\
32(42.2) \\
14(18.4)\end{array}$ & $\begin{array}{c}(28.5) \\
7(50.0) \\
3(21.5)\end{array}$ & $\begin{array}{l}1(25.0) \\
2(50.0) \\
1(25.0)\end{array}$ & $\begin{array}{c}0(0.0) \\
1(50.0) \\
1(50.0)\end{array}$ & $\begin{array}{l}1(25.0) \\
2(50.0) \\
1(25.0)\end{array}$ \\
\hline \multicolumn{6}{|c|}{$\operatorname{Serum}$ albumin $(\mathrm{gm} / \mathrm{dl})$} \\
\hline $\begin{array}{l}\geq 3.5 \\
<3.5\end{array}$ & $\begin{array}{c}68(89.5) \\
8(10.5)\end{array}$ & $\begin{array}{c}12(85.7) \\
2(14.3)\end{array}$ & $\begin{array}{l}2(50.0) \\
2(50.0)\end{array}$ & $\begin{array}{c}2(100.0) \\
0(0.0)\end{array}$ & $\begin{array}{l}2(50.0) \\
2(50.0)\end{array}$ \\
\hline \multicolumn{6}{|c|}{ Prothrombine time(sec) } \\
\hline $\begin{array}{l}\leq 15 \\
>15\end{array}$ & $\begin{array}{c}68(89.5) \\
8(10.5)\end{array}$ & $\begin{array}{c}12(85.7) \\
2(14.3)\end{array}$ & $\begin{array}{l}2(50.0) \\
2(50.0)\end{array}$ & $\begin{array}{c}2(100.0) \\
0(0.0)\end{array}$ & $\begin{array}{l}2(50.0) \\
2(50.0)\end{array}$ \\
\hline \multicolumn{6}{|c|}{ INR } \\
\hline $\begin{array}{l}\leq 1.5 \\
>1.5\end{array}$ & $\begin{array}{c}68(89.5) \\
8(10.5)\end{array}$ & $\begin{array}{c}12(85.7) \\
2(14.3)\end{array}$ & $\begin{array}{l}2(50.0) \\
2(50.0)\end{array}$ & $\begin{array}{c}2(100.0) \\
0(0.0)\end{array}$ & $\begin{array}{l}2(50.0) \\
2(50.0)\end{array}$ \\
\hline
\end{tabular}

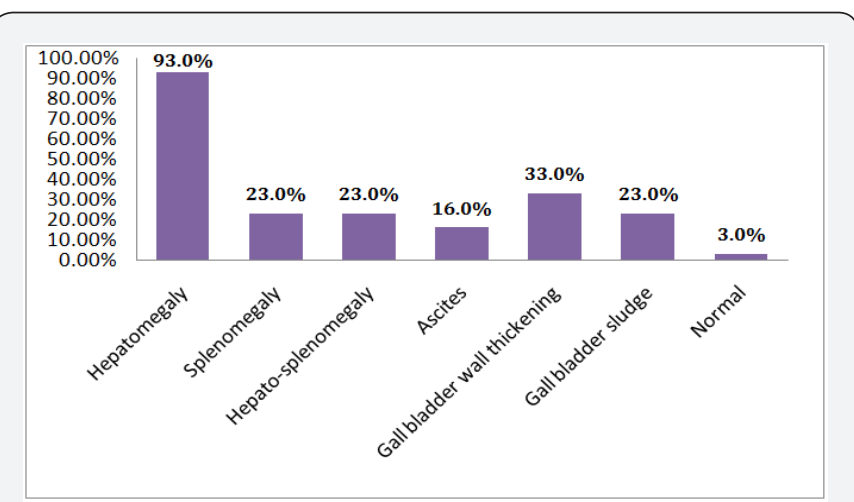

Figure 4: Ultrasound findings in viral hepatitis.

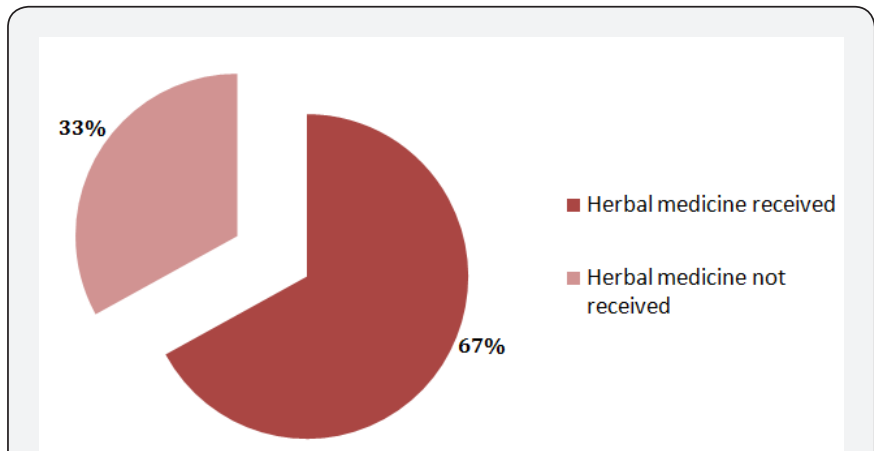

Figure 5: Intake of herbal medicine in studied children.

\section{Discussion}

Various studies in different parts of world including India, Pakistan, Nepal and Bangladesh have repeatedly shown that high rates feco-orally transmitted acute viral hepatitis is still a very important illness; with rates of HAV (3.1-67\%) and that of HEV (16.3-66.3.\%) in children [4,5,8,17-24]. Among studied children, 62 were male and 38 were female. So, male: female ratio was 1.6:1. Sarker et al. [5] (M:F ratio 1.6:1) from Bangladesh and Behera et al. [9] (M:F ratio 2.2:1) \& Rawat et al. [2] (M:F ratio 1.4:1) from India also stated that, boys are more commonly affected than girls.
In the present study, Out of 100 icteric children; most of the children were positive for anti-HAV IgM 76 (76.0\%), followed by anti-HEV IgM 14 (14.0\%). Sarker et al. [5] [Anti-HAV IgM $30(65.2 \%)$ \& anti-HEV IgM 16 (34.7\%)] from Bangladesh; Sudhamshu et al. [24] [Anti-HAV IgM 260(83.0\%) \& anti-HEV IgM 24 (8.0\%)] from Nepal, Behera et al. [9] [Anti-HAV IgM 48 (75.0\%) \& anti-HEV IgM 4(6.2\%)]; Poddar et al. [2] [Anti-HAV IgM 111 (64.5\%) \& anti-HEV IgM 28 (16.3\%)] and Yachha et al. [24] (Anti-HAV IgM 53\% \& anti-HEV IgM 13\%) from India also stated the near similar result. The seropositivity of HAV and HEV are quite high and alarming in Bangladesh as evident from this study. It is well known that these two viruses cause infections in over-crowded residential areas and spread by feco-oral route. One important issue as evident from this study is the very high seropositivity of HAV (76\%) infection in young children predominantly under 15 years of age. This indicates that HAV infection is acquired in early years of life. The younger population takes food and drinks from different fast food restaurants, open hotels, restaurants in crowded, slum areas where the hygiene is not properly maintained.Our study is closely correlate with the study by Samir k saha et al. [26] where they found overall anti-HAV sero-positivity was $69.6 \%$. Mahmud et al. 27 from Bangladesh also observed that, out of 254 children, 77 (44.7\%) were exposure to HAV within 5 years of age, 39 (70.9\%) children were exposure within 10 years of age and 25(92.6\%) were exposure within 15 years of age. A study conducted on school children in Delhi had found that all children by age of 16 years had antibodies to HAV. Study recommended that mass vaccination is not required in North India [7]. That's why in the present study, $>10$ year age group, HEV [9 (63\%)] infection were supreme over HAV [25 (33.0\%)] infection.

The higher seropositivity of HEV infection among adults (56.1\%) compared to children $(14.0 \%)$ in our study is also similar to that of research work published on population based studies in India 28 (17.7\%); Hong Kong 29(8.8\%) and Iran 30(8.5\%). Sarker et al. [5] (34.7\%) from Bangladesh; Patel et al. [31] (25.4\%) from Uganda observed the increasing seroprevalence of HEV infection in children. In the present study, HEV was absent in $1-5$ year age group, $37.0 \%$ in $5-10$ year age group and $63.0 \%$ in 
10-15 year age group. So, with increase of age infection gradually increase. This statement also established from previous study of same country. Labrique et al. [32] stated that seroprevalence of HEV in 1-5 year age group 0.6\%, 6-10 year age group 7.7\% and 11-15 year age group $11.6 \%$. Three studies from Egypt; china \& Uganda differs the result of present study in respect of $<5$ year of age. Fix et al. [33] (36.2\%) from Egypt; Lu et al. [34] (5.38\%) from China and Patel et al. [31] (31.0\%) from Uganda observed the increase number of HEV in 1-5 year age group. They data suggested that HEV infections may occur and cause disease as frequently in early childhood as it does in adults. It is possible that HEV infected children asymptomatic in early childhood or if symptomatic they are misdiagnosed or under-diagnosed as presence of another acute infection like HAV.

The incidence of acute hepatitis B (HBV) is largely reduced during the last 20 years as a result of the use of vaccination and routine blood donor screening globally [35,36]. However, acute HBV may still occur in adults and may results in fatal complications [37]. Nandi et al. [7] from India and Muchiri et al. [38] from Kenya were observed positivity of anti-HBcIgM $12.5 \%$ and $11.0 \%$ respectively among viral hepatitis of adult arena. Acute infection is more common with hepatitis B than $\mathrm{C}$ in childhood. The natural history of hepatitis $\mathrm{B}$ is well established in adults but the long-term outcome for children is still under debate. Following an acute infection, 90.0\% will recover spontaneously, but approximately $1.0 \%$ of patients develop acute fulminant hepatitis requiring Lamivudine/ Entecavir/Tenofobir or liver transplantation $[37,39,40]$. Unfortunately, access to liver transplantation is significantly limited by the shortage of organs, facility and by the high costs of the procedure [40]. Sarker et al. [5] 4 (8.0\%) \& Matin et al. [6] 7 (14.0\%) from Bangladesh; Shudhamshu et al. [24] 15 (5.0\%) from Nepal and Behera et al. [9] 9 (12.5\%) from India suggested that, acute HBV infection in children still persist like adult. In the studied children, positivity of anti-HBcIgM was only $4(4.0 \%)$ among all types of viral hepatitis. Mainly, three factors are responsible for these decreasing trends. Firstly, hepatitis B virus vaccine is now included in the EPI (Expanded Programme on Immunization) and is being provided free of cost for the last few years. Secondly, blood donor screening done routinely and accurately before blood transfusion. Finally, proper antenatal screening everywhere regarding HBV. In this study, two children were found positive from 5-10 year age group \& another 2 from 10-15 year age group. No acute B virus infection was found in 1-5 year age group. Matin et al. [6] from Bangladesh; Nandi et al. [7] \& Behra et al. [9] from India were observed the similar age related positivity. Acute HBV infection in early childhood may often a mild, non-specific, asymptomatic, subclinical illness that frequently passes without detection in approximately two thirds of cases [41].

In the present study, only $2(2.0 \%)$ cases were found with acute HCV infection. Bosan et al. [4] (2.5\%) from Pakistan observed the near similar result. From the previous study of Bangladesh, Sarker et al. [5] and Matin et al. [6] were not found any acute HCV infection in children. In acute phase, most of the (three quarters) children are symptomless. Minimal nonspecific and brief symptoms are initially found in approximately $15 \%$ of children [42]. So, lots of HCV infection in acute phase, underdiagnosed due to absence of symptoms.

Several studies from different parts of the world proved that, few cases were infected with multiple viruses at a time. Rawat et al. [2] and Behera et al. [9] from India, were found 2 cases of HAV with HEV co-infection. In a series of 44 cases of ALF, Arora et al. [20] have shown that HEV alone (15.0\%) or in combination with HAV $(27.5 \%)$ was responsible for $45.0 \%$ of cases and mortality was higher in this group than HAV alone. In the present study, 4 cases were found with HAV \& HEV co-infection. Poor hygiene with poor sanitary condition stimulate the HAV \& HEV coinfection as both are transmitted through feco-oral route.

Jaundice (100\%), anorexia (100\%), nausea \& vomiting (88.0\%), low grade fever (65.0\%) with right upper abdominal pain $(73.0 \%)$ were the common presenting symptoms. Sarker et al. [5] from Bangladesh, Sudhamshu et al. [24] from Nepal, Nandi et al. [7] and Behera et al. [9] from India observed the near similar result. Clinical characteristics were not much helpful in differentiating the viruses. Thus, serological testing is essential for correct etiological diagnosis. Nandi et al. [7] from southern India \& Kaur et al. [43] from North India reached similar conclusion in their study. Features of cholestasis like pale stool (18.0\%) \& pruritus (16.0\%) present except HCV. Nandi et al. [7] also found the near similar result. Cholestasis was commonest in HEV infection as documented in earlier Mechnik et al. [44] study. Relapsing course of hepatitis was seen in six children. All the children were infected with hepatitis A. Nandi et al. [7] also observed the similar result. On examination, hepatomegaly (94.0\%) may present almost all cases of viral hepatitis like other studies from different countries. Splenomegaly was present in $24 \%$ cases. Poddar et al. [22] (31.0\%) also observed the near similar result. Clinically detectable ascites was found in $14 \%$ cases. Poddar et al. [22] (21.6\%) observed the similar result but differs the Sarker et al. [5] (4.0\%) study. The pathophysiology of ascites in these cases is difficult to postulate; but serum albumin level in these cases was significantly lower than in those without ascites. Therefore, it can be postulated that these children already had hypoalbuminemia due to malnutrition and acute attack of viral hepatitis might have precipitated the ascites.

Again, like clinical characteristics, biochemical parameters were not much helpful in differentiating the viruses. Maximum number $(100 \%)$ of patients had increase serum bilirubin, ALT \& AST. Alkaline phosphatase $(20.0 \%)$ may increase in a case of pale stool (cholestasis). ALF may develop with ascites (14.0\%), low serum albumin (14.0\%) and increase prothrombine time/ INR in 14\% children. Eight from HAV, 2 from HEV, 2 from HBV and 2 from co-infection (HAV+HEV). Sudhamshu et al. [24] 1.6\% 
and Nandini et al. [2] $41.7 \%$ observed ALF children in viral hepatitis cases. It is may be due to usual to take herbal medicine either crude or purified of different preparations. Taking herbal medication in acute viral hepatitis is very common in our country. The message from a review article in Hepatology is clear that herbal medicines in acute viral hepatitis are a ticket to more trouble \& may progressed to liver failure anytime [45]. In the present study, out of 100 admitted patients, 67 (67.0\%) were having herbal medicines at the time of admission. Sudhamshu et al. [24] from Nepal also stated that among 85 admitted patients, $73 \%$ were having herbal medicines at the time of admission.

In ultrasound findings, hepatomegaly (93.0\%) was found in most of the cases followed by splenomegaly (23.0\%), gall bladder wall thickening $(33.0 \%)$, gall bladder sludge $(23.0 \%)$, hepatosplenomegaly $(23.0 \%)$ and ascites (16.0\%). Normal ultrasound was found in $3.0 \%$ cases (Figure 5). Sudhamshu et al. [24] from Nepal also observed the near similar result.

\section{Limitations of study}

It was conducted in a tertiary care hospital among hospitalized children. Hence, the clinical profile may not be generalized to the community. Second, we did not look for serology for nonhepatotrophic viruses like Epstein Barr virus, Herpes simplex virus and Cytomegalovirus. Further larger community-based studies are needed to know the sero-epidemiolgy of viral hepatitis in this part of the country.

\section{Conclusion}

Acute viral hepatitis is a major public health problem in Bangladesh. HAV remains the commonest cause of acute viral hepatitis in Bangladeshi children and HEV is the second one. $\mathrm{HAV}$ is the dominant one in $<10$ years of age but after 10 years, HEV infection is the supreme. Co-infection of HAV with HEV is not frequent but complicate any time with acute liver failure. Clinical and biochemical characteristics were not much helpful in differentiating the viruses. Thus, serological testing is essential for correct etiological diagnosis. Herbal medicine intake is still common in our country which deteriorating the clinical condition by hospital admission with or without liver failure.

\section{Future Prospect}

Better sanitation, provision of clean drinking water, proper sewage disposal, and public education are the mainstays for prevention of HAV and HEV infection. Universal vaccination against HAV and HBV should be the focus of authorities to prevent morbidity and mortality due to these common pathogens.

\section{References}

1. World Health Organization (WHO) (2013) Regional strategy for the prevention and control of viral hepatitis: Regional office for South-East Asia.

2. Rawat SK, Jain A (2015) Seroprevalence of Hepatitis A and E virus IgM in children suffering from acutehepatitis. J Med Sci Cli Res 3(3): 46164620 .
3. Sarthi M, Kumar KGR, Jayasimha VL, Kumar CSV, Patil SS, et al. (2017) Prevalence of hepatitis A virus as cause of acute viral hepatitis in central Karnataka, India. Inter J Con Ped; 4(1): 87-89.

4. Bosan A, Qureshi H, Bile KM, Ahmed I, Hafiz R (2010) A review of hepatitis viral infectionsin Pakistan. J Pak Med Assoc 60(12): 10451054.

5. Sarker NR, Saha SK, Ghosh DK, Adhikary A, Mridha A, et al. (2014) Seropositivity of viral markers in icteric children. Bangladesh Med J 43(1): 26-29.

6. Matin A, Islam MR, Mridha AA, Mowla MG, Khan R, et al. (2011) Hepatitis B \& C viral markers status in icteric children at a Tertiary Care Hospital. J Shaheed Suhrawardy Med Coll 3(2): 35-57.

7. Nandi GCB, Hadimani MP, Arunachalam CR, Ganjoo RK (2008) Spectrum of acute viral hepatitis in Southern India. Med J Arm for India 65(1): 7-9.

8. Jain P, Prakash S, Gupta S, Singh KP, Shrivastava S, et al. (2013) Prevalence of hepatitis A virus, hepatitis B virus, hepatitis C virus, hepatitis D virusand hepatitis E virus as causes of acute viral hepatitis in North India: A hospital based study. Indian J Med Microbiol 31(3): 261-265.

9. Behera MR, Patnaik L (2016) Clinico-biochemical profile and etiology of acute viral hepatitis in hospitalized children: A study from Eastern India. Indian J Child Health 3(4): 317-320.

10. Satsangi S, Dhiman RK (2016) Combating the wrath of viral hepatitis in India. Indian J Med Res 144(1): 1-5.

11. Fischler B, Baumann U, Dezsofi A, Hadzic N, Hierro L, Jahnel J et al (2016) Hepatitis E in children: A position paper by the ESPGHAN Hepatology Committee. JPGN 63(2): 288-294.

12. Alam S, Azam G, Mustafa G, Alam M, Ahmed N (2017) Past, present and future of hepatitis $B$ and fatty liver in Bangladesh. Gastroenterol Hepatol Open acces 6(3): 1-7.

13. Jobayer M, Chowdhury SS, Shamsuzzaman SM, Islam MS (2016) Prevalence of hepatitis Bvirus, hepatitis C virus and HIV in overseas job seekers of Bangladesh with the possible routes of transmission. Mymensingh Med J 25(3): 530-535.

14. World Health Organization (2016) Guidelines for the screening, care and treatment of persons with chronic hepatitis C infection. Geneva, Swizerland.

15. Mahtab MA, Rahman S, Karim F, Foster G, Solaiman S (2009) Epidemiology of hepatitis $C$ virus in Bangladeshi general population. Bangabandhu Sheikh Mujib Med Univ j 2(1): 14-17.

16. Ahad MA (2008) Current challenges in Hepatitis C TAJ 21(1): 93-96.

17. Irshad M, Singh S, Ansari MA, Joshi YK (2010) Viral hepatitis in India: A Report from Delhi. Glob J Health Sci 2: 96-103.

18. Jeong SH, Lee HS (2010) Hepatitis A: Clinical manifestation and management. Intervirology 53:15-19.

19. Acharya SK, Madan K, Dattagupta S, PandaSK (2006) Viral hepatitis in India. Natl Med JIndia 19(4): 203-217.

20. Arora NK, Nanda SK, Gulati S, Ansari IH, Chawla MK, et al. (1996) Acute viral hepatitis types $\mathrm{E}, \mathrm{A}$, and $\mathrm{B}$ singly and in combination in acute liver failure in children in north India. J Med Virol 48(3): 215-221.

21. Acharya SK, Batra Y, Hazari S, ChoudhuryV, Panda SK, et al. (2002) Etiopathogenesis of acute hepaticfailure:Eastern versus Western countries. J Gastroenterol Hepatol 17(3): 268-273.

22. Poddar U, Thapa BR, Prasad A, Singh K (2002) Changing spectrum of sporadic acute viral hepatitis in Indian children. J Trop Pediatr 48(4): 210-213. 
23. Kumar S, Ratho RK, Chawla YK, Chakraborti A (2007) The incidence of sporadic viral hepatitis in North India: A preliminary study. Hepatobiliary Pancreat Dis Int 6(6): 596-599.

24. Sudhamshu KC, Sharma D, Poudyal Nandu, Basnet BK (2014) Acute viral hepatitis in pediatric age groups. JNMA J Nepal Med Assoc 52(193): 687-691.

25. Yachha SK, Poddar U (2006) Acute viral hepatitis: Selected queries. Indian Ped 43(7): 600-602.

26. Saha SK, Saha S, Shakur S, Hanif M, Habib MA, et al. (2009) Communitybased cross-sectional seroprevalence study of hepatitis $A$ in Bangladesh. World J Gastroenterol 15(39): 4932-4937.

27. Mahmud S, Karim ASMB, Alam J, Islam MMZ, Sarker NK, et al. (2015) Hepatitis A virus vaccination strategy and pre-immunization screening of Bangladeshi children. Bangladesh J Med Sci 14(1): 65-68.

28. Amarapurkar D, Agal S, Baijal R, Gupte P, Patel N, et al. (2008) Epidemiology of hepatitis $\mathrm{E}$ virus infection in western India. Hepat Month 8(4): 258-262.

29. Lai JY (1997) Hepatitis A and E in Hongkong. HKMJ 3(1): 79-82.

30. Shamsizadeh A, Nikfar R, Makvandi M, Shamsizadeh N. (2009) Seroprevalence of HEV infection in children in the Southwest of Iran. Hep Monthly 9(4): 261-264.

31. Patel RC, Kamili S, Teshale E (2015) Hepatitis E virus infections in children age 0-15, Uganda outbreak, 2007. J Cli Virology 73: 112-114.

32. Labrique AB, Zaman K, Hossain Z (2009) Population seroprevalence of hepatitis E virus antibodies in rural Bangladesh. Am J Trop Med Hyg 81(5): 875-881.

33. Fix AD, Abdel-Hamid M, Purcell R, Shehata MH, Abdel-Aziz F, et al (2000) Prevalence of antibodies to hepatitis E in two rural Egyptian communities. Am J Trop Med Hyg 62(4): 519-523.

34. Lu J, Zhou Y, Lin X, Jiang Y, Tian R, et al. (2009) General epidemiological parameters of viral hepatitis $\mathrm{A}, \mathrm{B}, \mathrm{C}$, and $\mathrm{E}$ in six regions of China: a cross-sectional study. PLoS One 4(12): e8467.

35. Zanetti AR, Romano L, Zappa A, Velati C (2006) Changing patterns of hepatitis B infection in Italy and NAT testing for improving the safety of blood supply. J Clin Virol 36(1): S51-S55.

36. Centre for disease control and prevention (2004) Acute hepatitis B among children and adolescents, United States 53(43): 1015-18.

37. Lisotti A, Azzaroli F, Buonfiglioli F, Montagnani M, Alessandrelli F, et al. (2008) Lamivudine treatment for severe acute HBV hepatitis. Int J Med Sci 5(6): 309-12.

38. Muchiri I, Okoth FA, Ngaira J, Tuei S (2012) Seroprevalence of HAV, HBV, HCV and HEV among acute hepatitis patients at Kenyata National Hospital in Nairobi, Kenya. East Africa Med J 89(6): 199-205.

39. Kelly D (2006) Viral hepatitis B and C in children. J R Soc Med 99(7): 353-57.

40. Bruno R, Carosi G, Coppola N, Gaeta GB, Puoti M, et al. (2014) Recommendations for the management of acute hepatitis B: position paper of theItalian Society for the Study of Infectious and Tropical Diseases (SIMIT). Infection. Published online.

41. Kappus MR, Sterling RK (2013) Extrahepatic manifestations of Acute hepatitis B virus infection. Gastroenterol Hepatol (N Y) 9(2): 123-126.

42. El-guindi MA (2016) Hepatitis C virus infection in children: Updated review. Pediatr Gastroenterol Hepatol Nutr 19(2): 83-95.

43. Kaur R, Gur R, Berry N, Kar P (2002) Etiology of endemic viral hepatitis in urban North India. Southeast Asian J Trop Med Public Health 33(4): 845-48.

44. Mechnik LMD, Bergman N, Attali M, Beergabel M, Mosenkis B, et al (2001) Acute hepatitis E virus infection presenting as prolonged cholestatic jaundice. J Clin Gastroenterol 33(5): 421-22.

45. Bernuau JR, Durand F (2008) Herbal medicines in acute viral hepatitis: A ticket for more trouble. Eur J Gastroenterol Hepatol 20(3): 161-63.

\section{Your next submission with JuniperPublishers will reach you the below assets}

- Quality Editorial service

- Swift Peer Review

- Reprints availability

- E-prints Service

- Manuscript Podcast for convenient understanding

- Global attainment for your research

- Manuscript accessibility in different formats

( Pdf, E-pub, Full Text, audio)

- Unceasing customer service

Track the below URL for one-step submission https://juniperpublishers.com/online-submission.php 